\title{
Age-dependent morphology and ultrastructure of the cornua glands in drones of Apis mellifera*
}

\author{
Lien MOORS, Johan BILLEN
}

Zoological Institute, Katholieke Universiteit Leuven, Naamsestraat 59, box 2466, 3000 Leuven, Belgium

Received 16 December 2008 - Revised 26 February 2009 - Accepted 6 March 2009

\begin{abstract}
We investigated the age-dependent morphology and ultrastructure of the cornua glands in drones of Apis mellifera. Two epithelial types could be distinguished, each corresponding with a different type of cuticle. The thickness of both epithelia decreases during the period of sexual maturation. Ultrastructural research did not reveal a difference between the two epithelia.
\end{abstract}

morphology / cornua glands / Apis mellifera / drones

\section{INTRODUCTION}

The knowledge of the exocrine glands of social Hymenoptera is mainly based on studies of the female castes, whereas males have been rather neglected. Not only females, but also males are equipped with various exocrine glands performing different functions.

In drones of Apis mellifera L., the genital organs include a pair of testes, two vasa deferentia, which are partly enlarged as seminal vesicles, two accessory glands (= mucus glands), an ejaculatory duct and a complex internal penis or endophallus, which develops ontogenetically from the ectoderm (Zander, 1916; Snodgrass, 1941, 1956). The endophallus consists of a vestibulum from which a pair of large pouch-like cornua project laterally. Beyond the vestibulum, the endophallus consists of a slender neck, the cervix, the end of which supports an expansion of the bulbus (Snodgrass, 1956). Mating occurs high in the air and on the flight. During copulation, the drone everts his endophallus in the genital chamber of the queen (Woyke, 1958; Koeniger

Corresponding author: L. Moors, Lien.Moors@bio.kuleuven.be

* Manuscript editor: Klaus Hartfelder and Koeniger, 1991). The cornua are the first to be everted. First their tips turn dorsally and outwards, afterwards the cornua tubes bend downwards (Woyke, 1955) and their tips probably embrace the queen's abdomen (Woyke and Ruttner, 1958). Woyke (1955) suggested that the cornua remain outside the queen's body during copulation. Koeniger et al. (1996) were the first to attribute a glandular function to the cornua. As the endophallus turns inside out during mating, the cornua secretion becomes the outside layer. The function of the cornua and their secretion, however, is controversial. In several literature reports (Bishop, 1920; Snodgrass, 1956), the authors mention penetration of the cornua into the lateral pouches of the bursa copulatrix. Koeniger (1984) found in most individuals studied a partially everted state of the cornua. According to the same author, the cornua do not penetrate the lateral pouches of the bursa copulatrix. The paired cornua, with its secretory cells arranged as a monolayered epithelium corresponding with class-1 in the classification of Noirot and Quennedey (1974, 1991), are flattened tubes with a narrow distal tip and contain a sticky orange layer (Koeniger, 1986).

As in the synthesis of mucus in the mucus glands, the pigment of the orange secretion 
appears to be related to the sexual maturation of the drones with the highest measure at the age of 12 days, which is the age when drones are sexually mature (Mindt, 1962; Koeniger et al., 1990). In the case of fully everted cornua, the sticky orange layer is left inside the queen (Koeniger, 1984). According to Arnhart (1938), the structures are hanging freely in the dorsal abdominal region of the queen, others assume that the cornual structures do not enter the queen and that these surround the queen's abdomen in a way comparable to paramers in other insects (Woyke, 1955). Koeniger and Koeniger (2000) provide comparative data of the cornual appearance in cavity-dwelling, giant and dwarf honeybees. A general trend these authors report is the role of the cornua in attachment, more particularly by means of a sticky and greasy secretion.

Koeniger (1986) and Koeniger et al. (1990) showed that the cornua secretion becomes part of the mating sign, left by the drone after copulation. The mating sign of Apis mellifera consists of mucus from the mucus glands, expelled chitin plates from the bulbus and a sticky orange layer synthesized by cornua gland cells (Koeniger et al., 1996). As the mating sign can be removed by the next drone and the drones preferably grasp and mate with queens having a mating sign, the outside layer of the cornua glands may serve as an optical cue (Van Praagh et al., 1980; Vallet and Coles, 1993).

Furthermore, the sticky orange cornual secretion may reinforce the attachment between drones and queens and may keep the mating sign in place (Koeniger et al., 1996; Koeniger and Koeniger, 2000). Even the giant honeybees have elongated cornua to guarantee a strong connection between drones and queens while mating (Ruttner, 1975; Koeniger and Koeniger, 2000; Woyke, 2001). In contrast to the cavity-nesting honeybees and the giant honeybees, the dwarf honeybees possess other structures together with the cornua glands, such as a forceps-like appendix on the metatarsus of the hind legs, to strengthen the connection between the queen and the drones (Ruttner, 1975).

In this contribution, we report on the morphology and ultrastructure of the cornua glands of Apis mellifera carnica Pollmann drones of different ages, which represents the first ontogenetic study of these glands in bees.

\section{MATERIALS AND METHODS}

Drones of Apis mellifera were obtained from hives in Oberursel (Germany) and Kampenhout (Belgium). Cornua glands were studied in pupal drones (11, 12, 13 and 14 days after brood cell closure) and in drones captured 0, 3, 6, 9 and 12 days after emergence. We investigated six individuals per age. To obtain the different ages, newly emerged drones were paint-marked on the thorax and put in natural colonies until they attained the appropriate age. The glands were fixed in $2 \%$ glutaraldehyde (buffered at $\mathrm{pH} 7.3$ with $50 \mathrm{mM} \mathrm{Na-cacodylate} \mathrm{and}$ $150 \mathrm{mM}$ saccharose) and postfixed in $2 \%$ osmium tetroxide in the same buffer. After dehydration in a graded acetone series (50\%-70\%-90\%-100\%), the glands were embedded in Araldite and sectioned with a Reichert Ultracut E microtome. Semithin sections $(1 \mu \mathrm{m})$ for light microscopy were stained with methylene blue-thionin (1\%-1\%). Ultrathin sections $(70 \mathrm{~nm})$ were manually double stained with uranyl acetate and lead citrate and examined in a Zeiss EM900 electron microscope. The histochemical application of Farrants Gum with ethyl gallate is used to detect lipids in the secretions. This is a method for unsaturated lipids, involving the use of $\mathrm{OsO}_{4}$. Furthermore, we also used the Oil Red O staining on araldite sections. The use of this technique results in red lipid material. The Oil Red O solution used is $0.5 \%$ in $100 \%$ propylene glycol. Statistical analyses are performed with the computer program Statistica using matched pair T-test.

\section{RESULTS}

\subsection{Age-dependent histology}

The general structure of the cornua glands "in situ" is a flattened elongated tube with a narrow apical part. Histological sections show that the cornua glands are constituted by two epithelia with different types of cuticle morphology; one covered with a smooth cuticle and the other with a cuticle provided with indentations (Fig. 1A). Both types are visible in the pupal stages as well as in adult drones. The 

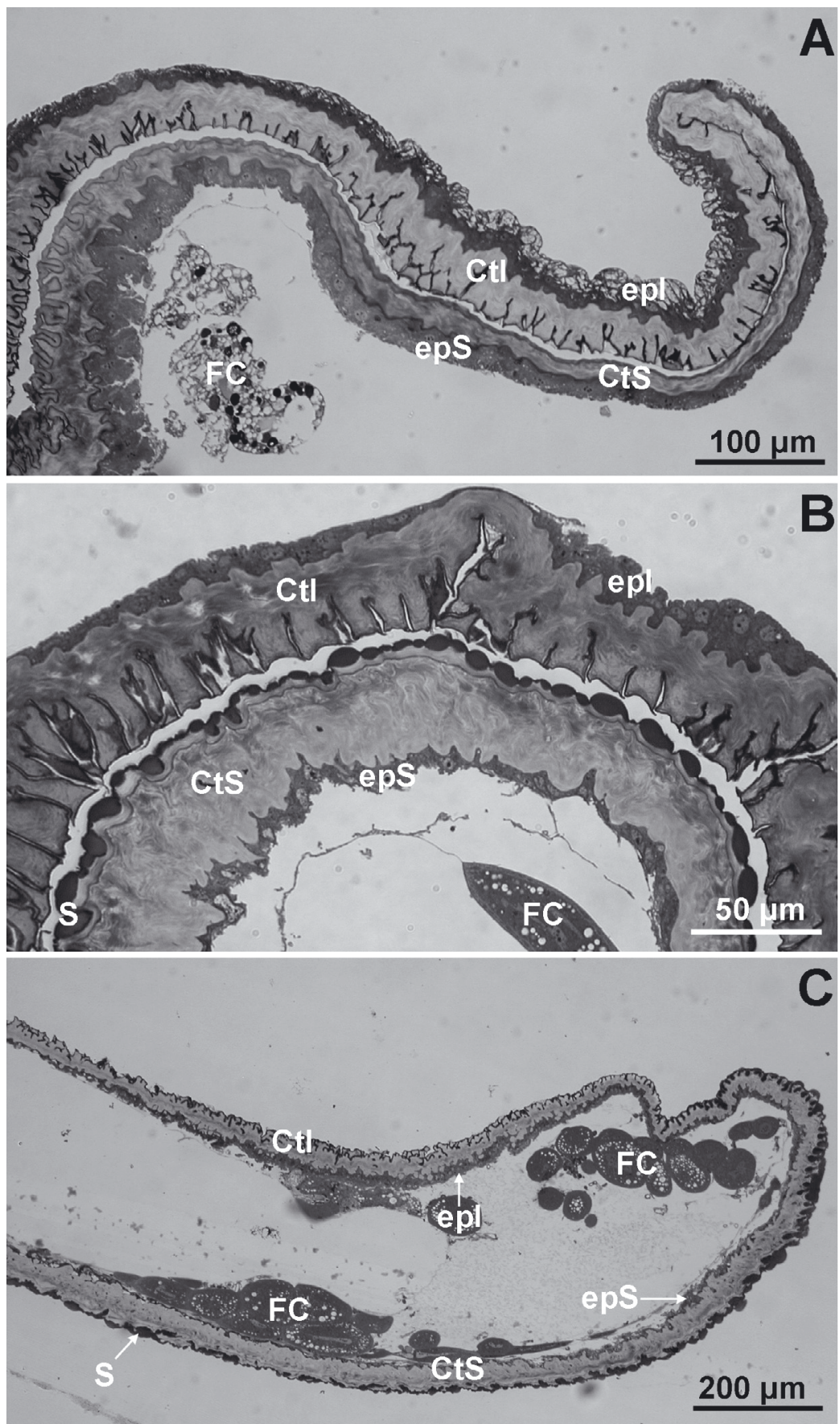

Figure 1. (A, B) Semithin longitudinal sections of the cornua in situ of a 0-day old and 9-day old drone, respectively. A: 2 different cuticle types, B: distribution of the secretion. (C) Semithin section of an everted cornua. CtI, cuticle with indentations; $\mathrm{CtS}$, smooth cuticle; FC, fat cells; $\mathrm{S}$, secretion; epS, epithelium on the side of the smooth cuticle; epI, epithelium lining the cuticle with indentations. 
cornual secretion is attached to the smooth cuticle (Fig. 1B). This is confirmed for all age classes examined in the non-everted state. In a functional context, the distribution of secretion in the everted cornua was also checked. In the everted state, the secretion is predominantly lining the smooth cuticle (Fig. 1C) which changes in a saw-like structure. Application of the method of Farrants Gum with ethyl gallate and the Oil-Red $\mathrm{O}$ in propylene glycol shows a high lipid content in the secretion of both epithelia of the cornua glands (Fig. 2). The epithelial thickness of the cornua glands in adult drones decreases from more of less $20 \mu \mathrm{m}$ to around $5 \mu \mathrm{m}$ for both epithelia. After day 3 the epithelial thickness on the side of the smooth cuticle started to decline (Fig. 3).

\subsection{Age-dependent ultrastructure}

In the present study, we investigated the two epithelium types and describe the most conspicuous ultrastructural changes, related with age.

\subsubsection{Epithelium with smooth cuticle}

\section{Pupae}

In the epithelium of 11 day-old pupae, microvilli are clearly visible as well as mitochondria. RER is present in its tubular form. The Golgi apparatus is abundant (Fig. 4A). The epithelium of 12-day-old pupae also shows mitochondria and tubular stacks of RER, but the Golgi apparatus is less abundant. The cuticle at this age is considerably thicker $(4 \mu \mathrm{m})$ than at 11 days $(1 \mu \mathrm{m})$. In 13-day-old pupae, mitochondria appear more abundant than in the two previous stages. There are no electron-lucid inclusions visible in the epithelium (Fig. 4B). The epithelium of 14-dayold pupae still shows microvilli, mitochondria, Golgi apparatus, tubular RER and a cuticle in the process of formation.

\section{Adults}

In callow individuals, the Golgi apparatus is abundant and RER is still present. Epithelial cells also lack electron-lucent structures
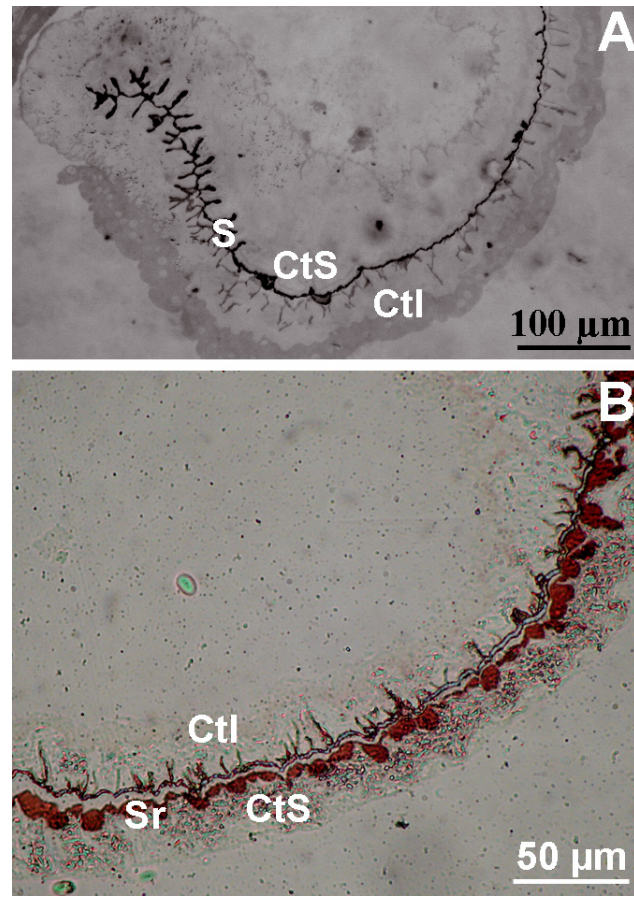

Figure 2. (A) Histochemical image of the uneverted cornua gland of a 3-day-old drone. Farrats Gum with ethyl gallate is used to detect lipids. (B) Histochemical image of the uneverted cornua gland of a 12-day-old drone. The Oil Red O solution used is $0.5 \%$ in $100 \%$ propylene glycol to detect lipids. $\mathrm{CtI}$, cuticle with indentations; $\mathrm{CtS}$, smooth cuticle; $\mathrm{S}$, secretion; Sr, secretion which colored red after staining.

as was the case in the pupal stage (Fig. 4C). At the age of 3 days, the Golgi apparatus is not that abundant anymore, but free ribosomes can be observed. The RER has a more vesicular appearance, whereas in the cytoplasm of pupae the tubular form was more prominent. The 6-day-old adult stage generally shows a decrease of RER, microvilli and Golgi apparatus. The latter is now more basally located in the epithelial cells. Contrarily, mitochondria are abundant. The epithelium of drones of 9 and 12 days old shows a general decrease of most organelles and of epithelial thickness. In the older ages there is secretion visible inside the cuticular layers. 


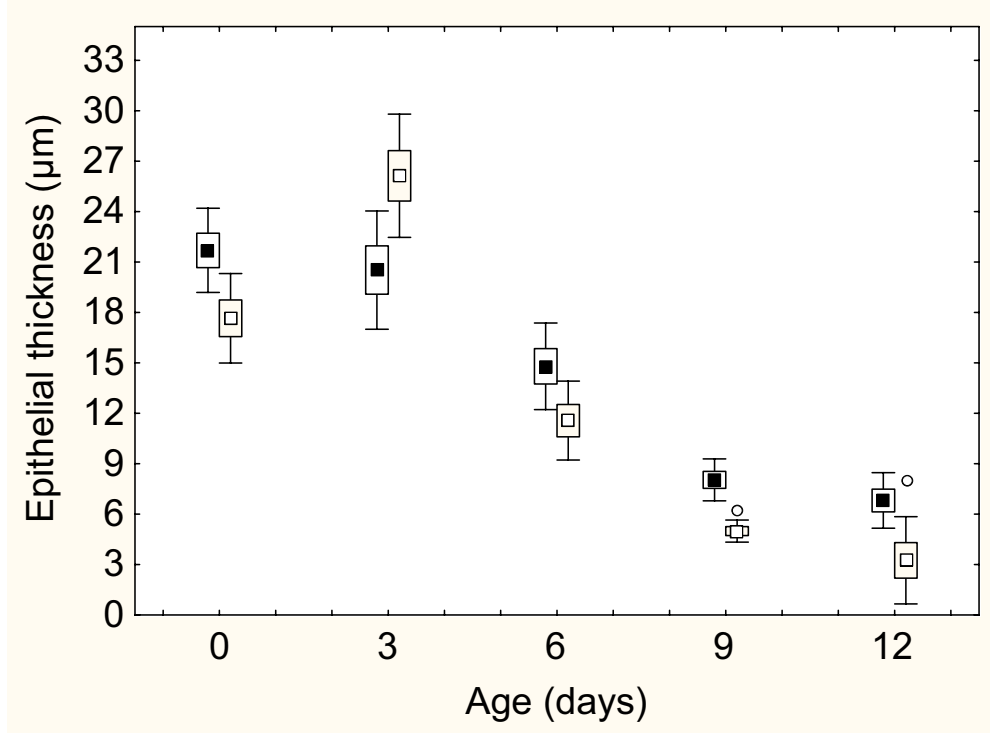

Figure 3. Epithelial thickness of the two different epithelia in relation to age $(n=6)$. The difference between the two epithelia at an age of 3 day was not significant $(P=0.063862)$. $\square$ Epithelium lining the indented cuticle; Epithelium lining the smooth cuticle; $\circ$ outliers.

\subsubsection{Epithelium with indented cuticle}

\section{Pupae}

The cuticle of 11-day-old pupae is not well developed, only an electron-dense lining is present. The epithelium does not show microvilli, RER is rather scarcely dispersed and in general few cytoplasmic inclusions are seen. The epithelium of 12-day-old pupae is characterized by the clear presence of mitochondria while RER, in its tubular form, is rather scarcely dispersed. The cuticle is becoming considerably thicker $(1.5 \mu \mathrm{m})$ than the electron-dense cuticular lining $(0.03 \mu \mathrm{m})$ of a 11-day-old pupae.

In the cytoplasm of 13-day-old and 14-day old pupae, microvilli are present as well as mitochondria. RER is present both in the vesicular and tubular form, but the latter is the most abundant.

\section{Adults}

Newly emerged drones have an epithelium with large amounts of Golgi apparatus, mitochondria and RER are also present (Fig. 5A). In 3-day-old drones, the epithelium still shows a lot of Golgi apparatus and few free ribo- somes, a situation contrasting with that of the epithelium with smooth cuticle at the same age. Vesicular rather than tubular RER is present (Fig. 5B). At the age of 6 days, the cytoplasm displays mitochondria and the Golgi apparatus is more abundant. Surprisingly, epithelia of adults of 9 and 12 days do not show a decrease of Golgi apparatus. In contrast with this, all other organelles are becoming less abundant (Fig. 5C). As the case of the smooth cuticle, the indented cuticle shows the presence of secretion inside its layers.

In the epithelia of most age classes, both pupae and adults, electron-lucid inclusions of unknown origin are found at the basal side of the cell. No additional data are available to allow an accurate description of these unknown structures. These inclusions, probably endosomal compartments, might be related to degenerative changes and/or changes during the secretory process.

\section{DISCUSSION}

The present study describes the presence of two different morphological regions, assumed 

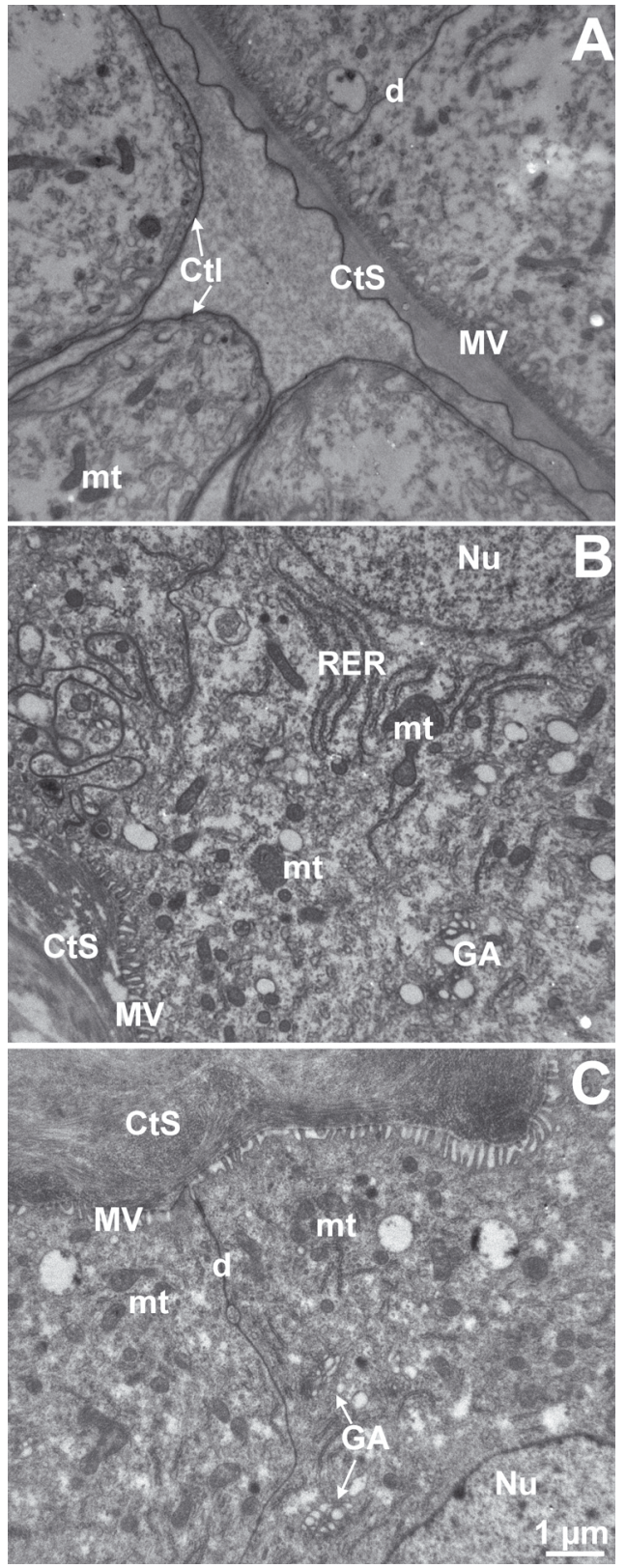

Figure 4. Ultrastructure of the epithelium lining the smooth cuticle of the cornua glands. (A) Detail of the apical region in a pupa of 11 days. (B) Detail of the cytoplasm in a pupa of 13 days. (C) Detail of the cytoplasm in a just emerged drone. d, desmosomes; CtS, smooth cuticle; CtI, indented cuticle; MV, microvilli; mt, mitochondria; GA, Golgi apparatus; $\mathrm{Nu}$, nucleus; RER, granular endoplasmic reticulum.
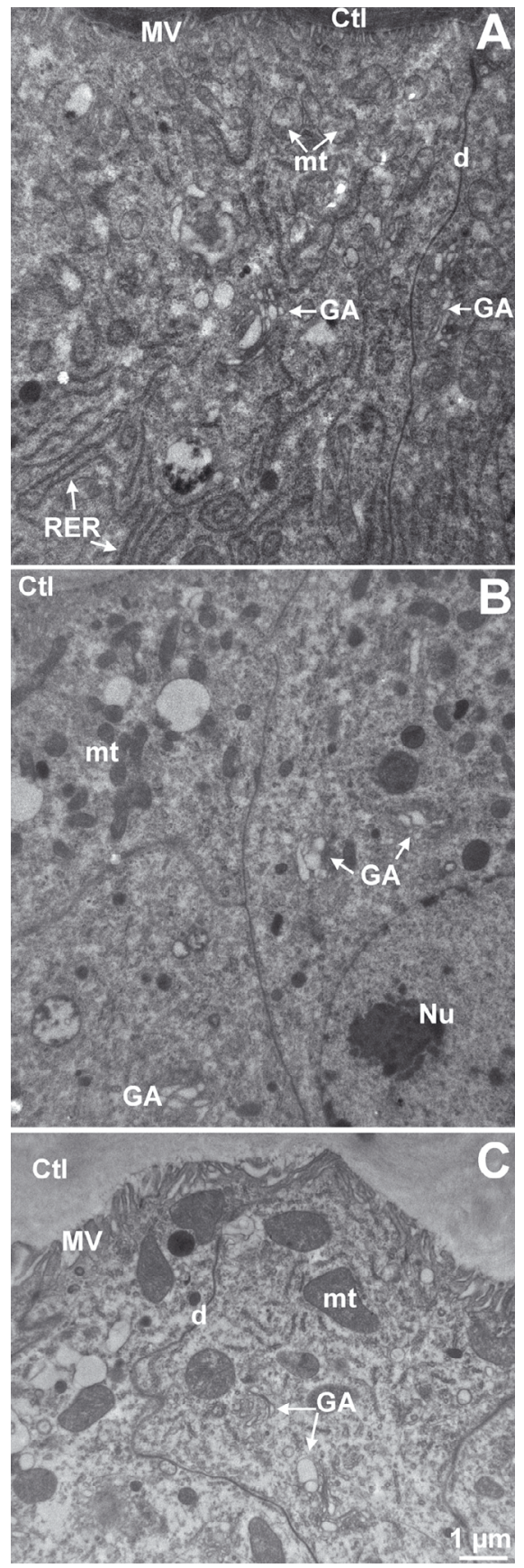

Figure 5. Electron micrographs of the epithelium with the indented cuticle. (A-C) Details of the apical region in adults of respectively 0,3 and 9 days. d, desmosomes; CtI, indented cuticle; MV, microvilli; mt, mitochondria; GA, Golgi apparatus; $\mathrm{Nu}$, nucleus; RER, granular endoplasmic reticulum. 
to have a different secretory activity. Both epithelial types show clear signs of secretory activity. Each investigated age revealed the presence of the Golgi apparatus in the cells of the cornua glands. This, together with the presence of fat cells surrounding the cornua glands, corresponds with the lipid nature of the secretion, as for the Dufour gland of ants (Billen, 1986), with several reports linking the lipid nature of the gland secretion with the well-defined presence of Golgi apparatus in the epithelial cells (Delfino et al., 1988 (wasps); Abdalla and da Cruz-Landim, 2001 (bees)). Indirect proof in the Dufour's gland of bumblebees that there is external uptake of material is the paucity of secretory organelles and secretion vesicles in the cells, suggesting no evident intracellular production of secretion in the gland. The abundance of GA might indicate a highly active trans-Golgi-network for the export of secretion (Abdalla et al., 1999).

From the histochemical point of view, our tests confirm the presence of lipids in the secretion. This is in accordance with the ultrastructural observation of Golgi apparatus in the epithelial cells, a previously unknown finding. Indeed, Koeniger et al. (1996) reported the absence of a Golgi apparatus. The observations of lipids in secretions are also supported by the histological observation of fat cells surrounding the cornua glands.

Our study shows the presence of secretion inside the cuticular layers, which is not unusual, since the secretion has to pass the cuticular barrier before reaching the lumen. A peculiar finding is that the secretion in the lumen always attaches to the smooth cuticle regardless of age. The secretion does not seem to be attached to the cuticle with indentations. The smooth cuticle contacts the secretion but apparently the pattern of indentations might influence the distribution of secretion attached to the smooth cuticle. Since this was found in all samples investigated, the possibility of being an artifact should be excluded. The different occurrence of secretion could be a functional and structural adaptation; attachment of secretion to only one cuticular region might facilitate detachment of the sticky secretion when everting the endophallus. This observation is supported by the everted state where the smooth cuticle is carrying the secretion. The indented cuticle can extend during eversion, while the smooth one cannot. As a result it bursts and slips, which causes the cornua to bend downwards as described by Woyke (1955). If all cuticle linings of the cornua were smooth, the secretion possibly would remain attached to the entire cuticle and hence contribute less to the intense color of the mating sign. In literature, it is reported that the cornua with its orange, sticky and lipidic secretion may contribute to strengthen the attachment of the drone to the queen. After copulation it then remains glued to the mating sign and keeps it into position (Koeniger et al., 1996; Koeniger and Koeniger, 2000).

The changes in epithelial thickness most likely are related to the secretory process, with an increase in early adult life and a decrease afterwards, with slight differences for the epithelium with smooth cuticle and the epithelium with indented cuticle. It appears that the epithelium with the smooth cuticle is slightly more active with its cuticle formed a bit earlier during pupal development and with a longer lasting increase of epithelial thickness until 3 days. However, there is no real explanation why the smooth cuticle increases at 3 days. It could be possible that there is more secretory activity at that age, but there were no significant ultrastructural differences between the two epithelial types.

\section{ACKNOWLEDGEMENTS}

We greatly thank An Vandoren for her help in tissue sectioning and Tom Wenseleers for his help with statistics. This research was supported through grant No. G.0699.08 of the Flemish Fund for Scientific Research.

Morphologie et ultrastructure des glandes des cornules des mâles d'abeilles (Apis mellifera) en fonction de l'âge.

Apis mellifera / mâle / morphologie / cornule / glande

Zusammenfassung - Altersabhängige Morphologie und Ultrastruktur der Cornualdrüsen der Drohnen von Apis mellifera. Im Unterschied zur 
Königin und den Arbeiterinnen wird den Drohnen vergleichsweise wenig Beachtung geschenkt. Jedoch trotz ihrer kurzen Lebensdauer kommt ihnen eine wichtige soziale Rolle zu, da ihr Sperma absolut notwendig ist, damit eine Königin weibliche Nachkommen produzieren kann. Während der Kopulation stülpt der Drohn den Endophallus aus, dessen Innenseite damit aussen zu liegen kommt. Wir untersuchten mittels Licht- und Elektronenmikroskopie und mithilfe histochemischer Methoden die Cornualdrüsen im nichtausgestülpten (in situ) und im ausgestülpten Zustand. Wir fanden zwei unterschiedliche Typen an Epithelien, eines das mit einer gezahnten und eines das mit einer glatten Cuticula bedeckt ist (Abb 1A). Interessant ist dabei die Sekretverteilung, die nur mit der glatten, nicht aber mit der gezahnten Cuticula assoziert ist (Abb. 1B). Histochemisch konnten wir zeigen, dass das Sekret eine grosse Menge an Lipiden enthält, was mit dem Befund eines ausgedehnten Golgiapparats in Einklang steht (Abb. 1D, 2 und 4). Wir fanden zwar, dass die Epitheldicke ab dem dritten Adulttag abnimmt (Abb. 2), konnten aber keine Unterschiede hinsichtlich der Sekretionsaktivität der beiden Epithelien erkennen.

\section{Morphologie / Cornualdrüsen / Apis mellifera / Drohnen}

\section{REFERENCES}

Abdalla F.C., da Cruz-Landim C. (2001) Dufour glands in Hymenoptera (Apidae, Formicidae, Vespidae): a review, Rev. Bras. Biol. 61, 95-106.

Abdalla F.C., Velthuis H.H.W., da Cruz-Landim C., Duchateau M.J. (1999) Changes in the morphology and ultrastructure of the Dufour's gland during the life cycle of the bumble bee, Bombus terrestris L. queen (Hymenoptera: Bombini), Neth. J. Zool. 49, 251-262.

Arnhart L. (1936) Der unausgestülpte Penis der Drohne von Apis mellifica L., Arch. Bienenkd. 63, $1-28$.

Billen J. (1986) Comparative morphology and ultrastructure of the Dufour gland in ants (Hymenoptera: Formicidae), Entomol. Gen. 11, 165-181.

Bishop G.H. (1920) Fertilization in the honeybee: the male sexual organs, their histological structure and physiological functioning, J. Exp. Zool. 31, 225267.

Delfino G., Turillazzi S., Calloni C. (1988) A light and electron microscope study on the Dufour's gland in Polistes gallicus (L.) (Hymenoptera: Stenogastrinae), Z. Mikrosk. Anat. Forsch. 102, 627-644.

Koeniger G. (1984) Funktionsmorphologische Befunde bei der Kopulation der Honigbiene (Apis mellifera L.), Apidologie 15, 189-204.
Koeniger G. (1986) Mating sign and multiple mating in the honeybee, Bee World 67, 141-150.

Koeniger N., Koeniger G. (1991) Evolutionary approach to mating behaviour and drone copulatory organs in Apis, Apidologie 22, 581-590.

Koeniger N., Koeniger G. (2000) Reproductive isolation among species of the genus Apis, Apidologie $31,313-339$.

Koeniger G., Wissel M., Herth W. (1990) Cornual secretion on the endophallus of the honeybee drone (Apis mellifera L.), Apidologie 21, 185-191.

Koeniger G., Hänel H., Wissel M., Herth W. (1996) Cornual gland in the honeybee drone (Apis mellifera L.): structure and secretion, Apidologie 27, 145-156.

Mindt B. (1962) Untersuchungen über das Leben der Drohnen, insbesondere Ernährung und Geschlechtsreife, Z. Bienenforsch. 6, 9-33.

Noirot C., Quennedey A. (1974) Fine structure of insect epidermal glands, Annu. Rev. Entomol. 19, 61-80.

Noirot C., Quennedey A. (1991) Glands, gland cells, glandular units: some comments on terminology and classification, Ann. Soc. Entomol. Fr. (N.S.), $27,123-128$.

Praagh J.P. van, Ribi W., Wehrhahn C., Wittmann D. (1980) Drones fixate the queen with the dorsal frontal part of their compound eyes, J. Comp. Physiol. 136, 263-266.

Ruttner F. (1975) Ein metatarsaler Haftapparat bei den Drohnen der Gattung Apis (Hymenoptera), Entomol. Gen. 2, 22-29.

Snodgrass R.E. (1941) The male genitalia of Hymenoptera, Smithsonian Institution, Washington, p. 86.

Snodgrass R.E. (1956) Anatomy of the Honey Bee, Comstock Publ. Assoc. Cornell Univ. Press, Ithaca N.Y., p. 343.

Vallet A.M., Colles J.A. (1993) The perception of small objects by the drone honeybee, J. Comp. Physiol. A. 172, 183-188.

Woyke J. (1955) Multiple mating of the honeybee queen (Apis mellifera L.) in one nuptial flight, Bull. Acad. Pol. Sic. 5, 175-180.

Woyke J. (1958) The histological structure of the reproductive organs of the drone, Poznan Soc. Friends Sci., Publ. Sect. Agric. Sylvic. 19, 38-50.

Woyke J. (2001) Eversion of the endophallus of Apis dorsata drones, Proc. VII IBRA Conf. on Tropical Bees and V Asian Apicultural Association Conference, Chiang Mai, 19-25 March, 2000, pp. 189-194.

Woyke J., Ruttner F. (1958) An anatomical study of the mating process in the honeybee, Bee World 1, 3-18.

Zander E. (1916) Die postembryonale Entwicklung des Geschlechtsapparates der Drohne (Apis mellifica L.), Z. Angew. Entomol. 3, 7-20. 